\title{
The Influence of Piperine on the Radioprotective Effect of Curcumin in Irradiated Human Lymphocytes
}

\section{Piperinin Işınlanmış İnsan Lenfositlerinde Kurkuminin Radyoprotektif Etkilerine Etkisi}

\author{
(1) Noora GHELISHLI1,2, (1) Arash GHASEMI3 ${ }^{3}$, (1) Seyed Jalal HOSSEINIMEHR ${ }^{1 *}$ \\ 1Mazandaran University of Medical Sciences, Faculty of Pharmacy and Pharmaceutical Sciences Research Center, Department of Radiopharmacy, Sari, Iran \\ 2Mazandaran University of Medical Sciences, Student Research Committee, Sari, Iran \\ 3 Mazandaran University of Medical Sciences, Faculty of Medicine, Department of Radiology and Radiation Oncology, Sari, Iran
}

\section{ABSTRACT}

Objectives: lonizing radiation (IR) induces DNA damage in normal cells, leading to genotoxicity. The radioprotective effects of co-treatment with curcumin and piperine were investigated against genotoxicity induced by IR in human normal lymphocytes.

Materials and Methods: Human blood samples were pretreated with curcumin at different concentrations $(5,10$, and $25 \mu \mathrm{g} / \mathrm{mL})$ and/or piperine $(2.5 \mu \mathrm{g} / \mathrm{mL})$ and then were exposed to IR at a dose $1.5 \mathrm{~Gy}$. The radioprotective effects of curcumin and piperine were assessed by micronucleus (MN) assay.

Results: Curcumin and piperine reduced the percentage of $\mathrm{MN}$ induced by IR in lymphocytes. Piperine alone significantly reduced genotoxicity induced by IR as compared to curcumin alone at all concentrations. An additive radioprotective effect was observed with combination of piperine and curcumin at the low concentration of $5 \mu \mathrm{g} / \mathrm{mL}$, while this synergistic effect was not observed with curcumin at the higher concentrations of 10 and $25 \mu \mathrm{g} / \mathrm{mL}$.

Conclusion: Piperine has a potent radioprotective effect at low concentration as compare to curcumin. However, an additive radioprotective effect was observed with co-treatment with piperine and curcumin at low concentration, while piperine increased the percentage of MN in normal lymphocytes when co-treated with curcumin at higher concentration.

Key words: Curcumin, piperine, radioprotective genotoxicity, ionizing radiation

\section{ÖZ}

Amaç: Iyonize radyasyon (IR) normal hücrelerde DNA hasarına neden olarak genotoksisiteye neden olur. Curcumin ve piperin ile ortak tedavinin insan normal lenfositlerinde iyonlaştırıcı radyasyonun neden olduğu genotoksisiteye karşı koruyucu etkileri araştırıldı.

Gereç ve Yöntemler: İnsan kan numuneleri, farklı konsantrasyonlarda (5, 10 ve $25 \mu \mathrm{g} / \mathrm{mL}$ ) kurkumin ve/veya $(2.5 \mu \mathrm{g} / \mathrm{mL})$ piperin içerisinde ile ön muamele edildi ve daha sonra 1.5 Gy'lik bir dozda IR'ye maruz bırakıldı. Curcumin ve piperinin radyo-koruyucu etkileri mikronükleus (MN) testi ile değerlendirildi.

Bulgular: Kurkumin ve piperin, lenfositlerde IR tarafından indüklenen MN yüzdesini azaltmıştır. Sadece piperin, tüm konsantrasyonlarda tek başına

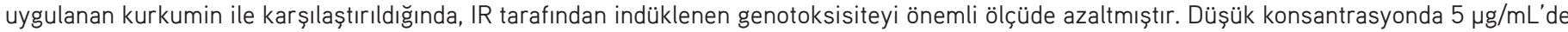
piperin ve kurkumin kombinasyonu ile ilave bir radyo-koruyucu etki gözlenirken, bu sinerjistik etki 10 ila 25 g/mL'lik yüksek konsantrasyonlarda kurkuminle gözlenmedi.

Sonuç: Piperin, kurkuminle karşılaştırıldığında düşük konsantrasyonda güçlü bir radyo-koruyucu etkiye sahiptir. Bununla birlikte, düşük konsantrasyonda piperin ve kurkumin ile birlikte yapılan muamele ile ilave bir radyo-koruyucu etki gözlenirken, piperin yüksek konsantrasyonda kurkumin ile birlikte muamele edildiğinde normal lenfositlerde MN oranını artırmıştır.

Anahtar kelimeler: Kurkumin, piperin, radyo-koruyucu genotoksisite, iyonize radyasyon

*Correspondence: E-mail: sjhosseinim@yahoo.com, Phone: 989113210663 ORCID-ID: orcid.org/0000-0001-8055-8036

Received: 27.05.2018, Accepted: 21.06.2018

-Turk J Pharm Sci, Published by Galenos Publishing House. 


\section{INTRODUCTION}

lonizing radiation (IR) is widely used for cancer treatment in patients. In this strategy, IR produces free radicals and reactive oxygen species (ROS) when passing through cells. These toxic substances react with critical macromolecules such as DNA, resulting in genotoxicity and cell death. While IR is focused on cancerous cells, unwanted exposure to normal cells results in damage to normal tissue. The side effects induced by IR limit the use of radiotherapy in patients. Radioprotective agents protect normal cells against genotoxicity and death induced by IR.,2 Several protection mechanisms are proposed for radioprotective agents such as free radical scavenging and increasing endogenous cellular antioxidants enzymes. ${ }^{2}$ Curcumin is a natural component that is prepared from Curcuma longa and widely used as an additive for flavoring in foods. This compound has several beneficial biological properties such as antioxidant, anti-inflammatory, and anticancer. ${ }^{3,4}$ Curcumin protects cells from genotoxicity and death induced by IR.,5 Poor bioavailability in oral consumption is the main disadvantage of curcumin for clinical application. ${ }^{7}$ It is interesting that some natural compounds act as an enhancer of curcumin through oral absorption. Piperine is a natural product prepared from black pepper (Piper nigrum L.). This natural product is consumed with $C$. longa as a spice in food. Piperine is used as an anticancer agent as well as a natural bioenhancer for curcumin. ${ }^{8}$ Piperine enhances the protective effects of curcumin against oxidative stress-related diseases in animal models.,10 Moreover, synergistic effects of curcumin and piperine were observed in the suppression of tumor proliferation in animals.1112 With respect to the beneficial effects of piperine and curcumin on oxidative stress and prevention of cancer, the aim of the present study was to investigate the influence of piperine on the radioprotective effect of curcumin against genotoxicity induced by IR on normal human lymphocytes.

\section{MATERIALS AND METHODS}

\section{Materials}

Curcumin was prepared from Sami Labs (India) and piperine was from Qingado BNP Co. (China). Phytohemagglutinin M (PHA-M), Roswell Park Memorial Institute (RPMI-1640) medium, fetal bovine serum (FBS), penicillin, and streptomycinL-glutamine were purchased from Gibco (USA). Cytochalasin-B was purchased from Sigma Chemicals Co. (St. Louis, MO, USA). Giemsa stain, methanol, and acetic acid were obtained from Merck (Germany).

\section{Blood treatment}

After obtaining permission from the research and ethical committees of Mazandaran University of Medical Sciences, this study was performed. Four healthy, nonsmoking male volunteers, aged from 22 to 28 years were enrolled. Twelve milliliters of whole blood was collected in heparinized tubes and divided among centrifuge tubes with $0.9 \mathrm{~mL}$ in each. Blood samples were pretreated with $100 \mu \mathrm{L}$ of solution of curcumin at a concentration of 5,10 , or $25 \mu \mathrm{g} / \mathrm{mL}$ and/or piperine $(2.5 \mu \mathrm{g} /$ $\mathrm{mL}$ ). These samples were incubated for $3 \mathrm{~h}$ at $37^{\circ} \mathrm{C}$. Curcumin
(CUR) and piperine (P) were dissolved in DMSO and diluted in RPMI cultural medium. The 12 samples groups were as follows: control, ionizing radiation (IR), $5 \mu \mathrm{g} / \mathrm{mL}$ CUR+IR, $10 \mu \mathrm{g} / \mathrm{mL}$ CUR+IR, $25 \mu \mathrm{g} / \mathrm{mL}$ CUR+IR, $5 \mu \mathrm{g} / \mathrm{mL}$ CUR+2.5 $\mu \mathrm{g} / \mathrm{mL}(P)+I R$, $10 \mu \mathrm{g} / \mathrm{mL}$ CUR+2.5 $\mu \mathrm{g} / \mathrm{mL}(P)+I R, 25 \mu \mathrm{g} / \mathrm{mL}$ CUR+2.5 $\mu \mathrm{g} / \mathrm{mL}$ (P)+IR, $2.5 \mu \mathrm{g} / \mathrm{mL}(P)+I R, 25 \mu \mathrm{g} / \mathrm{mL}$ CUR, $2.5 \mu \mathrm{g} / \mathrm{mL}(P), 5 \mu \mathrm{g} /$ $\mathrm{mL}$ CUR+2.5 $\mu \mathrm{g} / \mathrm{mL}(P)$. The curcumin concentrations were selected based on previous studies. 5,13 Piperine concentration was selected based on previous studies that showed $P$ has a $\mathrm{IC}_{50}$ of $61 \mu \mathrm{g} / \mathrm{mL}$ on the HeLa cell line ${ }^{14}$ and it did not exhibit any genotoxicity or cellular toxicity up to $60 \mu \mathrm{M}(17 \mu \mathrm{g} / \mathrm{mL}) .{ }^{15}$ Control samples were treated with diluted DMSO in RPMI at the same concentration as the other curcumin and/or piperine samples.

\section{lonizing radiation and micronucleus test}

Whole blood samples in microtubes were kept on a plastic box containing water as a phantom and then were irradiated with a $6 \mathrm{MV}$ X-ray beam produced by a linear accelerator (Siemens, Primus, Germany) at a dose of 1.5 Gy with a dose rate of 1.9 Gy/ min. Samples from four volunteers were allocated as controls (nonirradiated samples). After irradiation, subsequently, $0.5 \mathrm{~mL}$ of each sample (control and irradiated samples in duplicate) was added to $4.4 \mathrm{~mL}$ of RPMI 1640 culture medium, which contained a mixture of $10 \%$ FBS and $100 \mu \mathrm{L}$ of PHA. All cultures were incubated at $37^{\circ} \mathrm{C}$. Cytochalasin B (100 $\mu \mathrm{L}$ at final concentration: $6 \mu \mathrm{L} / \mathrm{mL}$ ) was added after $44 \mathrm{~h}$ of culture. Following $72 \mathrm{~h}$ of incubation, the cells were collected by centrifugation and resuspended in cold $0.75 \mathrm{M}$ potassium chloride. The cells were immediately fixed in a fixative solution of methanol:acetic acid $(6: 1 \mathrm{~V}: \mathrm{V})$ two times. The fixed cells were dropped onto clean microscopic slides, air dried, and stained with $10 \%$ Giemsa solution. All slides were evaluated at $1000 \times$ magnification in order to determine the frequency of micronuclei in the cytokinesis-blocked binucleated cells with a well-preserved cytoplasm. ${ }^{16}$ For each treated group from each volunteer, a total of 1000 binucleate cells (in the duplicate cultures) were examined to record the frequency of micronuclei-containing cells. All slides were evaluated by an expert using a light microscope. A total of 4000 binucleated lymphocytes were blindly counted in each treated group from three volunteers, and totally 48,000 binucleated lymphocytes were counted for the 12 treated groups in this study. The criteria for scoring micronuclei were a diameter between 1/16 and $1 / 3$ of the main nuclei, nonrefractile, not linked to the main nuclei, and not overlapping the main nuclei. ${ }^{16}$

\section{Statistical analysis}

The data values are presented as mean \pm standard deviation. The statistical analysis was performed using one-way ANOVA, as well as post hoc Tukey multiple comparison tests. A p value $<0.05$ was considered significant and highly significant (Prism 7 Software, 2016, USA).

\section{RESULTS}

A typical binucleated lymphocyte with a micronucleus is shown in Figure 1. The mean percentage of micronuclei in the irradiated samples was $8.57 \pm 0.09$, while it was $0.71 \pm 0.06$ in 
the nonirradiated control samples. It showed a statistically significant increase (12-fold rise) in the frequency of micronuclei in irradiated samples at a dose of 1.5 Gy (Table 1, Figure 2) ( $p<0.001)$. In irradiated samples with CUR pretreatment, the frequency of micronuclei at the concentrations of 5,10 , or 25 $\mu \mathrm{g} / \mathrm{mL}$ was $6.10 \pm 0.14 \%, 4.47 \pm 0.09 \%$, and $4.35 \pm 0.19 \%$ (Table 1). The data demonstrate that samples pretreated with CUR at concentrations of 5,10 , or $25 \mu \mathrm{g} / \mathrm{mL}$ exhibited a significant decrease in the frequency of micronuclei as compared to irradiated samples without CUR addition ( $p<0.001$ ). Total micronuclei frequencies were reduced by 1.40-, 1.92-, and 1.97fold in irradiated samples with CUR treatment at concentrations of 5,10 , or $25 \mu \mathrm{g} / \mathrm{mL}$, respectively, as compared to just irradiated samples (Table 1). The maximum protection of lymphocytes was observed with CUR treatment at a concentration of $25 \mu \mathrm{g} /$ $\mathrm{mL}$. A dose-manner protective effect was observed with CUR at concentrations of 5,10 , and $25 \mu \mathrm{g} / \mathrm{mL}$ ( $p<0.01$ ). However, the nonirradiated sample with CUR treatment at a concentration of $25 \mu \mathrm{g} / \mathrm{mL}$ did not show any increased genotoxicity as compared to the control group.

In irradiated samples with CUR+P pretreatment, the frequency of micronuclei at the concentrations of $5 \mu \mathrm{g} / \mathrm{mL}$ CUR+2.5 $\mu \mathrm{g} /$ $\mathrm{mL}(\mathrm{P})+\mathrm{IR}, 10 \mu \mathrm{g} / \mathrm{mL}$ CUR+2.5 $\mathrm{gg} / \mathrm{mL}(\mathrm{P})+\mathrm{IR}$, and $25 \mu \mathrm{g} / \mathrm{mL}$

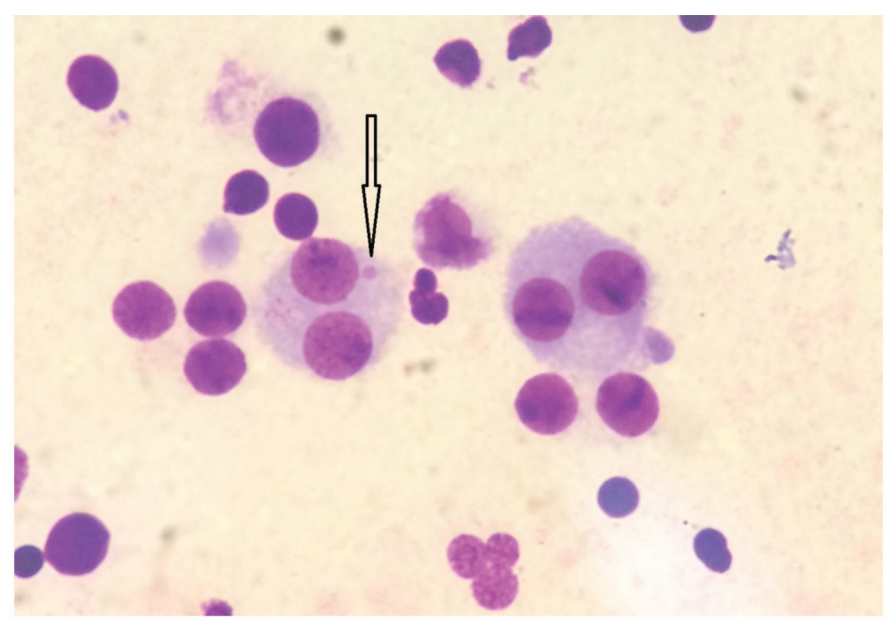

Figure 1. A typical binucleated lymphocyte with a micronucleus in our study

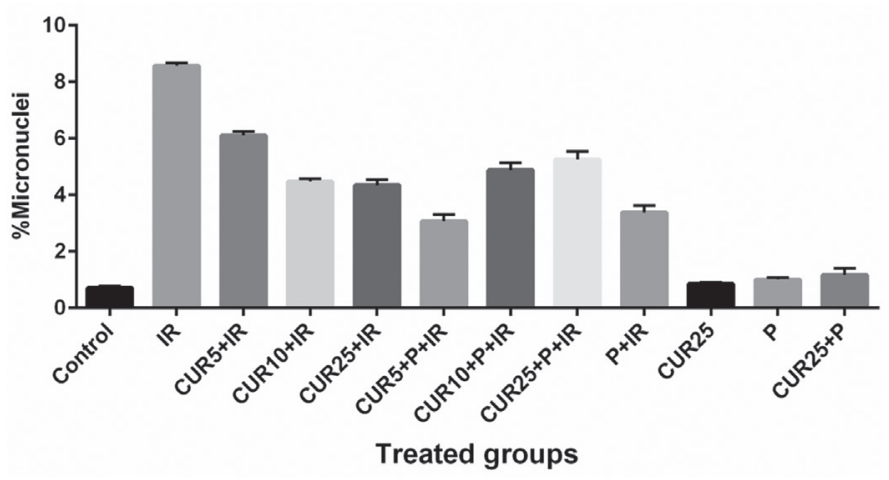

Figure 2. The effect of curcumin (CUR) and piperine (P) on frequency of micronuclei induced by 1.5 Gy X-ray radiation (IR) in cultured blood lymphocytes $(n=4)$
CUR+2.5 $\mu \mathrm{g} / \mathrm{mL}(P)+I R$ was $3.07 \pm 0.24 \%, 4.87 \pm 0.26 \%$, and $5.25 \pm 0.29 \%$, respectively (Table 1 ). The data demonstrate that pretreated samples with CUR $(5 \mu \mathrm{g} / \mathrm{mL})$ and $P(2.5 \mu \mathrm{g} / \mathrm{mL})$ exhibited significant decreases in the frequency of micronuclei as compared to irradiated samples with CUR alone at all concentrations $(5,10$ and $25 \mu \mathrm{g} / \mathrm{mL})$. It is interesting to see increased frequencies of micronuclei in human lymphocytes treated with CUR+P+IR as compared to CUR $(10 \mu \mathrm{g} / \mathrm{mL})+I R$ or CUR $(25 \mu \mathrm{g} / \mathrm{mL})+I R$ ( $p<0.05)$. Piperine significantly reduced the frequency of micronuclei in irradiated lymphocytes as compared to irradiation alone. The frequency of micronucleus lymphocytes with $\mathrm{P}$ at a concentration of $2.5 \mu \mathrm{g} / \mathrm{mL}$ was insignificant as compared to control samples, while the combination of CUR (25 $\mu \mathrm{g} / \mathrm{mL})$ and $P(2.5 \mu \mathrm{g} / \mathrm{mL})$ increased significantly the frequency of micronuclei in binucleated lymphocytes as compared to control samples (Table 1, Figure 2).

\section{DISCUSSION}

Curcumin, a natural product, is widely used in food and drug compositions and has several biological and pharmacological properties. Curcumin exhibits anticancer, anti-inflammatory, and antioxidant effects., ${ }^{3,4}$ Curcumin scavenges free radicals and $\mathrm{ROS}^{17}$ generated by toxic substances such as IR. The anti-inflammatory effect was reported for curcumin through diminishing cytokines and interleukins involved in the inflammation process. ${ }^{18}$ Oxidative stress and inflammation are two suggested main mechanisms involved in cellular toxicity induced by IR. Curcumin acts as a radioprotective agent through

Table 1. The frequency of micronuclei induced in vitro by 1.5 Gy

$X$-ray radiation (IR) in cultured blood lymphocytes at different

concentrations of curcumin and/or piperine $(P)(n=4)^{\mathrm{a}}$

\begin{tabular}{llllll} 
Volunteer & \multicolumn{5}{c}{ \% Micronuclei in binucleated lymphocytes } \\
\cline { 2 - 6 } treated group & I & II & III & V & Mean \pm standard deviation \\
\hline Control & 0.8 & 0.66 & 0.7 & 0.7 & $0.71 \pm 0.06$ \\
\hline IR & 8.6 & 8.5 & 8.7 & 8.5 & $8.57 \pm 0.09^{\mathrm{b}}$ \\
\hline CUR5+IR & 6 & 6.1 & 6.3 & 6 & $6.10 \pm 0.14^{\mathrm{c}}$ \\
\hline CUR10+IR & 4.6 & 4.5 & 4.4 & 4.4 & $4.47 \pm 0.09^{\mathrm{c}}$ \\
\hline CUR25+IR & 4.6 & 4.4 & 4.2 & 4.2 & $4.35 \pm 0.19^{\mathrm{c}}$ \\
\hline CUR5+P+IR & 2.9 & 3.1 & 2.9 & 3.4 & $3.07 \pm 0.24^{\mathrm{c}, \mathrm{d}}$ \\
\hline CUR10+P+IR & 5 & 5.1 & 4.5 & 4.9 & $4.87 \pm 0.26^{\mathrm{c}}$ \\
\hline CUR25+P+IR & 5 & 5.5 & 5.5 & 5 & $5.25 \pm 0.29^{c}$ \\
\hline P+IR & 3.5 & 3.5 & 3 & 3.5 & $3.37 \pm 0.25^{\mathrm{c}}$ \\
\hline CUR25 & 0.8 & 0.9 & 0.8 & 0.9 & $0.85 \pm 0.06^{\mathrm{e}}$ \\
\hline P & 1 & 1.1 & 0.9 & 1 & $1.00 \pm 0.08^{\mathrm{e}}$ \\
\hline CUR25+P & 1.00 & 1.5 & 1.2 & 1 & $1.17 \pm 0.24^{\mathrm{f}}$ \\
\hline
\end{tabular}

${ }^{a} 1000$ binucleated lymphocytes were examined in each sample, and 4000 binucleated lymphocytes from four volunteers in each group, ${ }^{b} p<0.001$ compared to control, cp<0.001 compared to IR, \#\#p<0.01 compared to control group, ${ }^{d} p<0.01$ compared to CUR5+IR, CUR10+IR, CUR25+IR, eNonsignificant compared to control, 'p<0.05 compared to control,

C: Control, IR: Ionizing radiation, CUR5: Curcumin $5 \mu \mathrm{g} / \mathrm{mL}$, CUR10: Curcumin $10 \mu \mathrm{g} /$ $\mathrm{mL}$, CUR25: Curcumin $25 \mu \mathrm{g} / \mathrm{mL}$, P: Piperine $2.5 \mu \mathrm{g} / \mathrm{mL}$ 
the two mentioned mechanisms. Recently we showed that curcumin had a protective effect against genotoxicity induced by radioactive iodine in human lymphocytes. ${ }^{5}$ Curcumin could selectively sensitize thyroid cancer cells to death induced by radioactive iodine without any toxicity on nonmalignant fibroblast cells. ${ }^{13}$ In the present study, we showed that curcumin significantly protected human healthy lymphocytes from genotoxicity induced by external IR. These results showed curcumin has a radioprotective effect on normal cells and a radiosensitizing effect on cancer cells, and so is promising for use as a natural agent in cancer therapy.

The highest radioprotection of lymphocytes with curcumin alone treatment was observed at a concentration of $25 \mu \mathrm{g} /$ $\mathrm{mL}$. Although this maximum protection is interesting, this concentration should be achieved in vivo by oral administration of curcumin. Curcumin could not achieve its expected therapeutic outcome in vivo due to its low solubility and poor bioavailability. The poor oral bioavailability of curcumin is due to its limited intestinal uptake and rapid metabolism and this is the biggest limitation of this natural product for human usage. ${ }^{7}$ Several strategies have been applied for enhancement of the oral bioavailability of curcumin such as improvement of its formulation ${ }^{19,20}$ and bioavailability enhancement. ${ }^{21}$ Piperine, as a major plant alkaloid, is widely used as a condiment and flavoring agent for many types of dishes. Piperine acts as an enhancer of the bioavailability and pharmacological activity of curcumin.11,22 There are two suggested mechanisms for piperine as a bioenhancer: promoting rapid absorption of drugs and nutrients and inhibiting enzymes involved in the biotransformation of drugs. Piperine is a potent inhibitor of the P-gp efflux transporter present in the gastrointestinal wall. ${ }^{21,23}$ Although the enhancing effect of piperine has been extensively studied in vivo for improvement of oral bioavailability, there are limited in vitro studies on the co-treatment of curcumin with piperine for cytoprotective effect or cytotoxicity. The uptake of curcumin was evaluated with curcumin-piperine mixture emulsion in Caco-2 cell cultures as a model for intestinal uptake. The extent of curcumin uptake was improved markedly by piperine addition. ${ }^{24}$ The combined effect of curcumin and piperine was studied on human osteogenic sarcoma cells. Curcumin combined with piperine suppressed osteoclastogenesis in vitro without causing any cytotoxic effects in periodontal ligament cells. ${ }^{25}$ Our study showed that piperine alone significantly reduced genotoxicity induced by IR in lymphocytes at a concentration of $2.5 \mu \mathrm{g} / \mathrm{mL}(8.7 \mu \mathrm{M})$ and was more potent than CUR at a concentration of $25 \mu \mathrm{g} / \mathrm{mL}$ (68 $\mu \mathrm{M})$. Piperine exhibited a 1.3-fold decrease in the frequency of micronuclei as compared to CUR, while the molar concentration of piperine was 8-fold lower than that of CUR. In the present study, piperine was used at a concentration of $2.5 \mu \mathrm{g} / \mathrm{mL}$ which was lower than that in other reports of the protective effects of piperine in vitro. ${ }^{26,27}$ For the first time, the present study showed that piperine exhibited a radioprotective effect in vitro on normal cells that was more potent than the effect of CUR. Recently the comparative efficacy of piperine and curcumin in deltamethrin (DLM) (DLM; a potent immunotoxicant)-induced splenic apoptosis and altered immune functions was evaluated. That study strongly demonstrated that piperine displayed more anti-oxidative, anti-apoptotic, and chemoprotective properties in the DLM-induced splenic apoptosis as compared to curcumin. ${ }^{28}$ Other studies have shown the protective effect of piperine against cellular toxicity induced by oxidative stress in cellular and animal models. The mechanisms of the protective effect of piperine are antioxidant, reduction of intracellular ROS level, reduction of levels of pro-inflammatory mediators, and anti-apoptotic. ${ }^{29,30}$ Piperine has a synergistic effect with CUR in reduction of micronucleus frequency in lymphocytes at a low concentration of CUR $(5 \mu \mathrm{g} / \mathrm{mL})$. In the present study, cotreatment with CUR $(5 \mu \mathrm{g} / \mathrm{mL})$ and piperine $(2.5 \mu \mathrm{g} / \mathrm{mL})$ showed the highest radioprotective effect against genotoxicity induced by IR on human lymphocytes, while no additive protective effects were observed with CUR at concentrations of 10 and $25 \mu \mathrm{g} / \mathrm{mL}$ with piperine. It is interesting that addition of piperine to CUR at concentrations of 10 and $25 \mu \mathrm{g} / \mathrm{mL}$ resulted in a reduction in protective efficacy as compared to CUR alone at these concentrations. On the other hand, CUR alone at concentrations of 10 and $25 \mu \mathrm{g} / \mathrm{mL}$ is more potent than addition of piperine to CUR (10 and $25 \mu \mathrm{g} / \mathrm{mL}$ ) for radioprotection. It is clear that the synergistic effect of CUR and piperine is concentration dependent and a diminishing radioprotective effect was observed with increasing concentration of CUR with piperine. Increased genotoxicity was observed in co-treatment with CUR and piperine at concentrations of $25 \mu \mathrm{g} / \mathrm{mL}$ and 2.5 $\mu \mathrm{g} / \mathrm{mL}$, respectively, on human normal lymphocytes. The exact mechanism of the cellular toxicity of piperine and CUR at high concentrations is unclear and future studies are needed for finding the exact mechanism.

\section{CONCLUSIONS}

In the present study, piperine exhibited a potential radioprotective effect at a low concentration of $2.5 \mu \mathrm{g} / \mathrm{mL}$ that was more potent than the effect of curcumin at a concentration up to $25 \mu \mathrm{g} / \mathrm{mL}$. The addition of piperine to curcumin at a low concentration of $5 \mu \mathrm{g} / \mathrm{mL}$ caused a synergistic effect as compared to curcumin alone in the radioprotective effect, while additional protection was not observed at higher concentrations of curcumin with piperine.

\section{ACKNOWLEDGEMENT}

This study was supported by a grant from Mazandaran University of Medical Sciences (grant number 2773).

Conflict of Interest: No conflict of interest was declared by the authors.

\section{REFERENCES}

1. Hosseinimehr SJ, Ahmadi A, Beiki D, Habibi E, Mahmoudzadeh A. Protective effects of hesperidin against genotoxicity induced by $(99 \mathrm{~m}) \mathrm{Tc}-\mathrm{MIBI}$ in human cultured lymphocyte cells. Nucl Med Biol. 2009;36:863-867.

2. Hosseinimehr SJ. Trends in the development of radioprotective agents. 
Drug Discov Today. 2007;12:794-805.

3. Hosseinimehr SJ. A review of preventive and therapeutic effects of curcumin in patients with cancer. Journal of Clinical Excellence. 2014;2:13.

4. Agrawal DK, Mishra PK. Curcumin and its analogues: potential anticancer agents. Med Res Rev. 2010;30:818-860.

5. Shafaghati N, Hedayati M, Hosseinimehr SJ. Protective effects of curcumin against genotoxicity induced by 131-iodine in human cultured lymphocyte cells. Pharmacogn Mag. 2014;10:106-110.

6. Sebastia N, Montoro A, Montoro A, Almonacid M, Villaescusa Jl, Cervera J, Such E, Silla A, Soriano JM. Assessment in vitro of radioprotective efficacy of curcumin and resveratrol. Radiation Measurements. 2011;46:962-966.

7. Liu W, Zhai Y, Heng X, Che FY, Chen W, Sun D, Zhai G. Oral bioavailability of curcumin: problems and advancements. J Drug Target. 2016;24:694702.

8. Shoba G, Joy D, Joseph T, Majeed M, Rajendran R, Srinivas PS. Influence of piperine on the pharmacokinetics of curcumin in animals and human volunteers. Planta Med. 1998;64:353-356.

9. Rinwa P, Kumar A. Piperine potentiates the protective effects of curcumin against chronic unpredictable stress-induced cognitive impairment and oxidative damage in mice. Brain Res. 2012;1488:38-50.

10. Singh S, Jamwal S, Kumar P. Piperine Enhances the Protective Effect of Curcumin Against 3-NP Induced Neurotoxicity: Possible Neurotransmitters Modulation Mechanism. Neurochem Res. 2015;40:1758-1766.

11. Patial V, S M, Sharma S, Pratap K, Singh D, Padwad YS. Synergistic effect of curcumin and piperine in suppression of DENA-induced hepatocellular carcinoma in rats. Environ Toxicol Pharmacol. 2015; $40: 445-452$

12. Sehgal A, Kumar M, Jain M, Dhawan DK. Modulatory effects of curcumin in conjunction with piperine on benzo(a)pyrene-mediated DNA adducts and biotransformation enzymes. Nutr Cancer. 2013;65:885-890.

13. Hosseinimehr SJ, Hosseini SA. Radiosensitive effect of curcumin on thyroid cancer cell death induced by radioiodine-131. Interdiscip Toxicol. 2014;7:85-88

14. Paarakh PM, Sreeram DC, D SS, Ganapathy SP. In vitro cytotoxic and in silico activity of piperine isolated from Piper nigrum fruits Linn. In Silico Pharmacol. 2015;3:9.

15. Thiel A, Buskens C, Woehrle T, Etheve S, Schoenmakers A, Fehr M, Beilstein P. Black pepper constituent piperine: genotoxicity studies in vitro and in vivo. Food Chem Toxicol. 2014;66:350-357.

16. Fenech M. The in vitro micronucleus technique. Mutat Res. 2000;455:8195.

17. Aftab N, Vieira A. Antioxidant activities of curcumin and combinations of this curcuminoid with other phytochemicals. Phytother Res.
$2010 \cdot 24: 500-502$

18. Okunieff $P, X u J, H u D$, Liu W, Zhang L, Morrow G, Pentland A, Ryan $\mathrm{JL}$, Ding I. Curcumin protects against radiation-induced acute and chronic cutaneous toxicity in mice and decreases mRNA expression of inflammatory and fibrogenic cytokines. Int J Radiat Oncol Biol Phy. 2006:65:890-898

19. Schiborr C, Kocher A, Behnam D, Jandasek J, Toelstede S, Frank J. The oral bioavailability of curcumin from micronized powder and liquid micelles is significantly increased in healthy humans and differs between sexes. Mol Nutr Food Res. 2014;58:516-527.

20. Sasaki H, Sunagawa Y, Takahashi K, Imaizumi A, Fukuda H, Hashimoto T, Wada H, Katanasaka Y, Kakeya H, Fujita M, Hasegawa K, Morimoto T. Innovative preparation of curcumin for improved oral bioavailability. Biol Pharm Bull. 2011;34:660-665.

21. Ajazuddin, Alexander A, Qureshi A, Kumari L, Vaishnav P, Sharma M, Saraf S, Saraf S. Role of herbal bioactives as a potential bioavailability enhancer for Active Pharmaceutical Ingredients. Fitoterapia. 2014;97:114.

22. Tu YS, Fu JW, Sun DM, Zhang JJ, Yao N, Huang DE, Shi ZQ. Preparation, characterisation and evaluation of curcumin with piperine-loaded cubosome nanoparticles. J Microencapsul. 2014;31:551-559.

23. Singh DV, Godbole MM, Misra K. A plausible explanation for enhanced bioavailability of P-gp substrates in presence of piperine: simulation for next generation of P-gp inhibitors. J Mol Model. 2013;19:227-238.

24. Gülseren I, Guri A, Corredig M. Effect of interfacial composition on uptake of curcumin-piperine mixtures in oil in water emulsions by Caco-2 cells. Food Funct. 2014;5:1218-1223.

25. Martins CA, Leyhausen G, Volk J, Geurtsen W. Curcumin in Combination with Piperine Suppresses Osteoclastogenesis In Vitro. J Endod. 2015;41:1638-1645.

26. Fu M, Sun ZH, Zuo HC. Neuroprotective effect of piperine on primarily cultured hippocampal neurons. Biol Pharm Bull. 2010;33:598-603.

27. Pathak N, Khandelwal S. Cytoprotective and immunomodulating properties of piperine on murine splenocytes: an in vitro study. Eur $J$ Pharmacol. 2007;576:160-170.

28. Kumar A, Sharma N. Comparative efficacy of piperine and curcumin in deltamethrin induced splenic apoptosis and altered immune functions. Pestic Biochem Physiol. 2015;119:16-27.

29. Ma Y, Tian M, Liu P, Wang Z, Guan Y, Liu Y, Wang Y, Shan Z. Piperine effectively protects primary cultured atrial myocytes from oxidative damage in the infant rabbit model. Mol Med Rep. 2014;10:2627-2632.

30. Mao $Q Q$, Huang Z, Ip SP, Xian YF, Che CT. Protective effects of piperine against corticosterone-induced neurotoxicity in PC12 cells. Cell Mol Neurobiol. 2012;32:531-537. 